\title{
'Streptomyces nanchangensis', a producer of the insecticidal polyether antibiotic nanchangmycin and the antiparasitic macrolide meilingmycin, contains multiple polyketide gene clusters
}

\author{
Yuhui Sun, ${ }^{1,2,3}$ Xiufen Zhou, ${ }^{1,2,4}$ Jun Liu, ${ }^{1,2}$ Kai Bao, ${ }^{1,2}$ Guiming Zhang, ${ }^{2}$ \\ Guoquan Tu, ${ }^{3}$ Tobias Kieser ${ }^{4}$ and Zixin Deng ${ }^{1,2,4}$
}

Author for correspondence: Zixin Deng. Tel: +8621 62933404. Fax: +862162933404. e-mail: zxdeng@mail.sjtu.edu.cn

1 Bio-X Life Science Research Center, Shanghai Jiaotong University, Shanghai 200030, China

2 Huazhong Agricultural University, Wuhan 430070, China

3 Jiangxi Agricultural University, Nanchang 330045, China

4 John Innes Centre, Colney, Norwich NR4 7UH, UK
Several independent gene clusters containing varying lengths of type I polyketide synthase genes were isolated from 'Streptomyces nanchangensis' NS3226, a producer of nanchangmycin and meilingmycin. The former is a polyether compound similar to dianemycin and the latter is a macrolide compound similar to milbemycin, which shares the same macrolide ring as avermectin but has different side groups. Clusters A-H spanned about 133, 132, 104, 174, 122, 54, 37 and 59 kb, respectively. Two systems were developed for functional analysis of the gene clusters by gene disruption or replacement. (1) Streptomyces phage $\phi \mathrm{C} 31$ and its derived vectors can infect and lysogenize this strain. (2) pSET152, an Escherichia coli plasmid with $\phi \mathrm{C} 31$ attP site, and pHZ1358, a Streptomyces-Escherichia coli shuttle cosmid vector, both carrying oriT from RP4, can be mobilized from E. coli into NS3226 by conjugation. pHZ1358 was shown to be generally useful for generating mutant strains by gene disruption and replacement in NS3226 as well as in several other Streptomyces strains. A region in cluster A ( $\sim 133 \mathrm{~kb})$ seemed to be involved in nanchangmycin production because replacement of several DNA fragments in this region by an apramycin resistance gene [aac3(IV)] gave rise to nanchangmycin non-producing mutants.

Keywords: antibiotic biosynthetic genes, dianemycin, avermectin, polyketide synthase, gene replacement in Streptomyces

\section{INTRODUCTION}

Streptomycetes produce a wide variety of commercially important polyketide compounds, including the wellknown macrolide, polyene and polyether antibiotics which exhibit antibacterial, antifungal, anthelmintic, antitumour and immunosuppressive activities. Biosynthesis of these antibiotics is catalysed by a large family of polyketide synthases (PKSs) using malonyl-CoA, methylmalonyl-CoA and ethylmalony-CoA as extender units for building the polyketide backbone (Hopwood, 1997; Katz, 1997; Leadlay, 1997).

Abbreviations: PKS, polyketide synthase; DEBS, 6-deoxyerythronolide $B$ synthase; ACP, acyl carrier protein; KS, ketosynthase; KR, ketoreductase; AT, acyltransferase; TE, thioesterase.
Many gene clusters encoding the enzymes of polyketide biosynthesis have been cloned and characterized (see Schwecke et al., 1995; Xue et al., 1998; Ikeda et al., 1999, for examples). Modular type I PKSs consisting of several large multifunctional proteins catalyse the biosynthesis of 'complex' or 'reduced' polyketides, the founding example being the erythromycin PKS (Cortes et al., 1990; Donadio et al., 1991). Combinatorial biosynthesis has been especially successful with many actinomycete PKSs following extensive structural and functional studies, and has led to the production of many 'unnatural natural products' (Cane et al., 1998; Hopwood, 1997; Hutchinson, 1998; Katz \& McDaniel, 1999).

'Streptomyces nanchangensis' was isolated from the soil in Nanchang, China (Ouyang et al., 1984). 'Str. 




Fig. 1. The structure of nanchangmycin, a polyether antibiotic with similar structure to dianemycin. The 14 bonds presumably formed by the PKSs are numbered; bold lines indicate the building units. Acetate is used as the starter unit. Condensation steps 3, 6, 8 and 9 would involve malonyl extender units and the others, methylmalonyl units. Steps 6,10 and 11 would be followed by ketoreduction, and steps 3, 7 and 12 by ketoreduction and dehydration. Steps 2, 4, 8 and 14 are followed by ketoreduction, dehydration and enoyl reduction, and steps 1, 5, 9 and 13 by no keto group modification. Oxidation occurred at the methyl group of step 1 and two double bonds are formed at steps 3 and 7 . Six-membered ring formation would involve hemiketal formation between a keto group introduced at step 9 and a hydroxyl at step 11. Cascade cyclizations form between keto groups at step 1, 5 and 9, and oxidized double bonds at steps 3 and 7, respectively.

nanchangensis' produces at least two kinds of insecticidal antibiotics (Ouyang et al., 1993). The polyether nanchangmycin (Fig. 1) structurally and biologically resembles dianemycin (Czerwinski \& Steinrauf, 1971), which is used in poultry farming. The 16-membered macrolide meilingmycin (Fig. 2a) resembles milbemycin $\alpha 11$ (Takahashi et al., 1993) and has a similar aglycone and antiparasitic activity as avermectin (Fig. 2b; Burg et al., 1979). In addition, 'Str. nanchangensis' produces at least two other antibiotics of unknown structure but with clearly different biological activities. Both meilingmycin and nanchangmycin are very active against a broad spectrum of harmful nematodes and insects, and are non-toxic for mammals and plants (Ouyang et al., 1993). Their chemical structures (Figs 1 and 2) indicate that they are both synthesized by modular type I PKSs.

Here we describe the cloning and characterization of multiple PKS gene clusters from 'Str. nanchangensis' NS3226 and show that they all contain typical type I PKS modules. Among the gene clusters isolated, one was shown to encode nanchangmycin biosynthesis. We also describe the development of a pIJ101-derived vector system that allows analysis and manipulation of antibiotic production genes by the efficient generation of mutant strains through directed gene disruption and replacement.

\section{METHODS}

Bacterial strains, phages and plasmids. These are described in Table 1. pHZ1351 was constructed by the incorporation of pIJ2925 [a pUC18 derivative with modified polylinker (Janssen \& Bibb, 1993)] into the unique EcoRI site of pHZ209, a pIJ101-derived $s t i^{+}$vector (Z. Deng, unpublished). A spontaneous deletion that removes a $693 \mathrm{bp}$ pIJ101 sequence (nt 7740-8432) and creates a NarI site at the junction (CGACGGCGCCTG) is localized in a region that is thought to be important for plasmid maintenance (Kieser et al., 1982). pHZ1358 is a derivative of pHZ1351 for cosmid cloning and conjugation from E. coli. pHZ1358 was constructed by first removing the two PstI fragments $(0.35$ and $0.95 \mathrm{~kb})$ of pHZ1351 and then replacing the BglII fragment containing pIJ2925 with SuperCos 1 (Evans et al., 1989) linearized with BglII. Secondly, the $2 \cdot 2 \mathrm{~kb} H i n d I I I-X b a I$ fragment of SuperCos 1 was replaced with a $0.8 \mathrm{~kb}$ HindIII-XbaI fragment from pHZ132 (Hu et al., 1994) containing oriT.

DNA probes. Five probes from the Saccharopolyspora erythraea erythromycin PKS gene cluster (Bevitt et al., 1992; Donadio \& Katz, 1992; Donadio et al., 1991) were excised from Escherichia coli plasmids kindly supplied by P.F. Leadlay (Cambridge University, UK) and purified from agarose gels using the Gene Clean kit (Bio101). The DEBS (6deoxyerythronolide $\mathrm{B}$ synthase) probe is a $3.2 \mathrm{~kb} \mathrm{Sacl}$ fragment containing genes for KR4 (ketoreductase 4), ACP6 (acyl carrier protein 6), KS6 (ketosynthase 6) and AT7 (acyltransferase 7) domains; the KR 4 probe is a $375 \mathrm{bp} \mathrm{Smal} \mathrm{fragment} \mathrm{containing}$ the gene for KR in the DEBS3 PKS; the AT7 probe is an $854 \mathrm{bp}$ Smal fragment containing most of the gene for AT in the DEBS3 PKS; the KS5 probe is a 519 bp SacI-Sall fragment containing most of the fifth KS function of DEBS3; the TE (thioesterase) probe is a $621 \mathrm{bp} \mathrm{SmaI} \mathrm{fragment} \mathrm{containing} \mathrm{the}$ thioesterase-cyclase function of DEBS3.

Culture techniques, transformation and conjugation. 'Str. nanchangensis' NS3226 and its derivatives were grown on GS medium (2\% soluble starch, $0 \cdot 1 \% \mathrm{KNO}_{3}, 0 \cdot 05 \% \mathrm{~K}_{2} \mathrm{HPO}_{4}$, $0.05 \% \mathrm{MgSO}_{4} .7 \mathrm{H}_{2} \mathrm{O}, 0.05 \% \mathrm{NaCl}, 0.001 \% \mathrm{FeSO}_{4}, 2 \%$ agar, $\mathrm{pH} 7 \cdot 5$ ) or YEME liquid medium (Kieser et al., 2000) at $28^{\circ} \mathrm{C}$ for growth of mycelium and isolation of total DNA, R2YE agar medium for transformation and protoplast regeneration (Kieser et al., 2000), YD medium (0.4\% Difco yeast extract, $1 \%$ maltose extract, $0 \cdot 4 \%$ glucose, $0 \cdot 2 \% \mathrm{MgCl}_{2}, 0 \cdot 15 \%$ $\mathrm{CaCl}_{2}, 2 \%$ agar, $\mathrm{pH} 7 \cdot 5$ ) for conjugation and $\mathrm{B} 2-1$ liquid medium $(3 \%$ corn powder, $1 \%$ corn starch, $1 \%$ soy bean powder, $0 \cdot 2 \% \mathrm{KH}_{2} \mathrm{PO}_{4}, 0 \cdot 05 \% \mathrm{MgSO}_{4}, 0 \cdot 05 \% \mathrm{NaCl}, 0 \cdot 2 \%$ $\left.\left(\mathrm{NH}_{4}\right)_{2} \mathrm{SO}_{4}, 1 \% \mathrm{CaCO}_{3}, \mathrm{pH} 7 \cdot 5\right)$ for fermentation. Protoplast preparation was according to Hopwood et al. (1985).

E. coli strains were cultured according to Sambrook et al. (1989). Cosmid clones were selected after infection of E. coli LE392 on L agar containing $100 \mu \mathrm{g}$ ampicillin $\mathrm{ml}^{-1}$ or $10 \mu \mathrm{g}$ apramycin $\mathrm{ml}^{-1}$. For Streptomyces, apramycin and thiostrepton were both used at $10 \mu \mathrm{g} \mathrm{ml}^{-1}$ in GS agar medium and at $5 \mu \mathrm{g} \mathrm{ml}^{-1}$ in liquid media.

Cloning techniques. Plasmid and total DNA was isolated from Streptomyces strains using 'procedure 3' of Hopwood et al. (1985). For the generation of cosmid libraries, total DNA samples were partially digested with $\mathrm{MboI}$, dephosphorylated with calf intestinal alkaline phosphatase and size fractionated by sucrose gradient centrifugation (Hopwood et al., 1985). The DNA fragments were mixed at a 1:1 molar ratio with BamHI-digested cosmid vectors and ligated at $\sim 200 \mu \mathrm{g}$ DNA $\mathrm{ml}^{-1}$. Packaging was done with $\lambda$ packaging mixes prepared according to Sambrook et al. (1989).

Antibiotic assay. Production of nanchangmycin was detected using a bioassay and HPLC. The strains were grown at $28^{\circ} \mathrm{C}$ for 5-7 d on GS agar medium. Agar plugs were transferred to $\mathrm{L}$ agar containing Bacillus cereus 1126, which is sensitive to nanchangmycin. Inhibition zones were visible after $12 \mathrm{~h}$ incubation at $37^{\circ} \mathrm{C}$. For HPLC analyses, the strains were cultured in $40 \mathrm{ml}$ B2-1 fermentation medium in $250 \mathrm{ml}$ baffled flasks at $28{ }^{\circ} \mathrm{C}$ and shaken at 220 r.p.m. for 7 d. After the mycelia were harvested by centrifugation at $600 \mathrm{~g}$ for $10 \mathrm{~min}$, 




(a) (b)
Fig. 2. The structure of meilingmycin (a), a macrolide structurally and biologically similar to milbemycin $\alpha 11$, and avermectin (b). Meilingmycin differs from avermectin in having no $\alpha$-L-oleandrose attached at position 13 of the macrolide ring (implication of an extra or functional dehydratase and enoyl reductase domains for step 13) but has an isopantenoic acid moiety at position 4 , which is probably derived from valine. The difference in the side group at position 25 probably reflects the flexibility of the starter unit in avermectin biosynthesis. the products were extracted with an equal volume of methanol. The extract was directly applied to HPLC on a Waters Xterra RP18 $5 \mu \mathrm{m}(3.9 \times 150 \mathrm{~mm})$ column. The mobile phase was acetonitrile/water $(85: 15)$ and the flow rate was $1 \mathrm{ml} \mathrm{min}$ at room temperature. The effluent was monitored at $243 \mathrm{~nm}$ with a Waters 996 photodiode array detector. The data were processed with a Waters Millennium Chromatography Manager.

Sequence analysis. Regions with spontaneous mutations in the pIJ101-derived vector pHZ1351 were sequenced using pBluescript II $\mathrm{SK}(+)$ or $\mathrm{SK}(-)$ as vectors. Sequencing reactions were done using the Amersham Thermosequenase sequencing kit containing fluorescent dye terminators. M13 forward and reverse primers (24-mers) and the recommended standard PCR conditions $\left(30\right.$ cycles; $1 \mathrm{~min} 96^{\circ} \mathrm{C}, 2 \mathrm{~min} 50^{\circ} \mathrm{C}$ and $4 \mathrm{~min} 60^{\circ} \mathrm{C}$ ) were used.

\section{RESULTS}

\section{Hybridization with an erythromycin PKS gene probe from Sac. erythraea identified eight independent PKS gene clusters from 'Str. nanchangensis' NS3226}

Probing Southern transfers of total DNA of NS3226 with a labelled $3.2 \mathrm{~kb}$ fragment from the DEBS3 erythromycin (ery) PKS gene (containing KR4, ACP6, KS6 and AT7 as a contiguous fragment) of Sac. erythraea involved in the biosynthesis of the 14-membered macrolide erythromycin gave many strong signals at low stringency $\left(6 \times \mathrm{SSC}, 65^{\circ} \mathrm{C}\right)$. To isolate the hybridizing sequences a genomic library of NS3226 DNA was constructed using the bifunctional cosmid vector $\mathrm{pHZ}$ 1358 (see Fig. 6b). Ninety cosmids with a mean insert size of $35-40 \mathrm{~kb}$ hybridized to the $3.2 \mathrm{~kb}$ ery probe at low stringency and were picked from a library with a total of 1920 clones. Comparison of the PvuII digestion patterns of the 90 cosmids revealed multiple overlapping bands. Moreover, at least one and up to 14 PvuII fragments from each of the 90 cosmids hybridized to the $3.2 \mathrm{~kb}$ ery probe, indicating a large number of partially homologous PKS-encoding sequences.

Ordering of the cosmids was achieved by comparing PvuII (and BamHI) digests of the cosmids. Cosmids producing similar bands were grouped and fractionated again on agarose gels until the most likely order of the cosmids was found (Figs 3 and 4). The order of the cosmids and restriction maps were further confirmed by Southern hybridization at high stringency $(0 \cdot 2 \times$ SSC, $65^{\circ} \mathrm{C}$ ) to prove the same origins of similar bands, using stepwise probes along the putative contigs (Figs 3 and 4). Seventy-five out of the 90 cosmids were thus grouped into eight independent clusters. Cluster A (Fig. 3) consists of 17 cosmid clones that hybridized to the ery PKS probe and spans $\sim 133 \mathrm{~kb}$ of continuous DNA. An $\sim 89 \mathrm{~kb}$ PKS-homologous region was located in the central part of the cluster; $28 \mathrm{~kb}$ flanking the left side, and at least $14 \mathrm{~kb}$ to the right of the PKS-homologous regions did not hybridize to the ery probe even at low stringency $\left(6 \times \mathrm{SSC}, 65^{\circ} \mathrm{C}\right)$. Cluster B (Fig. 4) has an $\sim 87 \mathrm{~kb}$ PKS-homologous region in a $\sim 132 \mathrm{~kb}$ contig (17 cosmids) and cluster $\mathrm{C}$ (Fig. 4) has an $\sim 86 \mathrm{~kb}$ PKShomologous region in $\mathrm{a} \sim 104 \mathrm{~kb}$ contig (7 cosmids). PKS-homologous regions in other clusters $(\mathrm{D}, \sim 174 \mathrm{~kb}$; $\mathrm{E}, \sim 122 \mathrm{~kb} ; \mathrm{F}, \sim 54 \mathrm{~kb} ; \mathrm{G}, \sim 37 \mathrm{~kb} ; \mathrm{H}, \sim 59 \mathrm{~kb}$; Fig. 4), as detected using the $3.2 \mathrm{~kb}$ ery probe only containing KR4, ACP6, KS6 and AT7, are either not concentrated in one or two contiguous regions (e.g. clusters D and $\mathrm{E}$ in Fig. 4) or not as large as in clusters $\mathrm{A}-\mathrm{C}(\sim 10 \mathrm{~kb}$ in cluster F, $\sim 11 \mathrm{~kb}$ in cluster $\mathrm{G}$ and $\sim 33 \mathrm{~kb}$ in cluster $\mathrm{H}$ ) along each contig.

Use of small probes encoding the KR4, AT7 and KS5 domains of the ery PKS refined the hybridization studies. The KR4, AT7 and KS5 probes give multiple signals in different regions of all the eight clusters (not shown), indicating that every gene cluster covered by the overlapping cosmid clones contain typical repetitive PKS modules. None of the cosmid clones, however, hybridized to the TE probe of the erythromycin pathway.

\section{Localization of contigs to five different 'Str. nanchangensis' Asel fragments separated by PFGE}

AseI digestion of 'Str. nanchangensis' NS3226 DNA generates $\sim 19$ macro-restriction fragments (Fig. 5) that can be separated by PFGE. The precise number of bands is not certain because several bands are clearly multiple, but $\sim 17$ bands can be detected in a single gel. These were transferred to nylon membrane and hybridized at high stringency $\left(0.2 \times \mathrm{SSC}, 65^{\circ} \mathrm{C}\right)$ against representative cosmids from each cluster as probes. Clearly, ${ }^{32} \mathrm{P}-$ 
Table 1. Strains, phages and plasmids used in this study

\begin{tabular}{|c|c|c|}
\hline Strain, phage or plasmid & Characteristics* & Source or reference \\
\hline \multicolumn{3}{|l|}{ 'Str. nanchangensis' strains } \\
\hline NS3226 & Wild-type producer for nanchangmycin and meilingmycin & Ouyang et al. (1984) \\
\hline SYH1 & $\begin{array}{l}\text { Non-producer for nanchangmycin generated by gene replacement of } \\
\text { region N1 in cluster A (see Fig. 3) }\end{array}$ & This work (see Fig. 7a) \\
\hline SYH2 & As above, but replacing region N2 of cluster A (see Fig. 3) & This work \\
\hline SYH8 & As above, but replacing region N3 of cluster A (see Fig. 3) & This work \\
\hline \multicolumn{3}{|l|}{ Str. lividans 66 strains } \\
\hline JT46 & str-6 pro- 2 & Tsai \& Chen (1987) \\
\hline \multicolumn{3}{|l|}{ E. coli $\mathrm{K}-12$ strains } \\
\hline DH5 $\alpha$ & $\mathrm{F}^{-}$recA lacZ $\Delta \mathrm{M} 15$ & Hanahan et al. (1983) \\
\hline ET12567 & dam dcm hsdS & MacNeil et al. (1992) \\
\hline LE392 & $\begin{array}{l}\text { supE44 supF58 hsdR514; used for infection with in vitro-packaged } \\
\text { cosmids }\end{array}$ & Borck et al. (1976) \\
\hline \multicolumn{3}{|l|}{ Bacillus cereus strain } \\
\hline 1126 & Indicator strain sensitive to nanchangmycin & Ouyang et al. (1984) \\
\hline \multicolumn{3}{|l|}{ Streptomyces phages } \\
\hline$\phi \mathrm{C} 31$ & Wild-type phage & Lomovskaya et al. (1972) \\
\hline KC301 & $\phi \mathrm{C} 31$ derivative; $c^{+} a t t^{+} t s r$ & Hopwood et al. (1985) \\
\hline KC505 & $\phi \mathrm{C} 31$ derivative; $c^{-} a t t^{-} t s r v p h$ & Hopwood et al. (1985) \\
\hline KC515 & $\phi \mathrm{C} 31$ derivative; $c^{+} a t t^{-} t s r v p h$ & Hopwood et al. (1985) \\
\hline KC516 & $\phi \mathrm{C} 31$ derivative; $c^{+} a t t^{-} t s r v p h$ & Hopwood et al. (1985) \\
\hline KC518 & $\phi \mathrm{C} 31$ derivative; $c^{-} a t t^{-} t s r v p h$ & Hopwood et al. (1985) \\
\hline$\phi \mathrm{HAU} 3$ & Wild-type phage & Zhou et al. (1994) \\
\hline pIJ8300 & $\phi$ HAU3-derivative; bla $v p h$ & Zhou et al. (1994) \\
\hline pIJ8301 & $\phi \mathrm{HAU} 3$-derivative; bla & Zhou et al. (1994) \\
\hline \multicolumn{3}{|l|}{ Plasmids } \\
\hline pIJ702 & pIJ101 derivative; $t s r$ mel $\mathrm{Ltz}^{-} s t i^{-}$ & Katz et al. (1983) \\
\hline pIJ486 & pIJ101 derivative; $t s r L_{t z^{-}} s t i^{-}$ & Ward et al. (1986) \\
\hline pHZ1351 & pIJ101 derivative; $t s r \mathrm{Ltz}^{-} s t i^{+}$ & This work (see Fig. 6a) \\
\hline pHZ1358 & $\begin{array}{l}\text { Cosmid for construction of NS3226 genomic library, pIJ101 } \\
\text { derivative; } t s r \mathrm{Ltz}^{-} \text {sti } i^{+} \text {oriT }\end{array}$ & This work (see Fig. 6b) \\
\hline pIJ922 & $\mathrm{SCP} 2 *$ derivative; $t s r \mathrm{Ltz}^{-}$ & Lydiate et al. (1985) \\
\hline pIJ61 & SLP1.2 derivative; $t s r \mathrm{Ltz}^{+}$ & Thompson et al. (1982) \\
\hline pWOR120 & pJV1 derivative; $t s r$ mel & Bailey et al. (1986) \\
\hline pSET152 & $\operatorname{aac} 3(I V)$ lacZ rep ${ }^{\mathrm{puc}}$ att ${ }^{\Phi \mathrm{C} 31}$ ori $T$ & Bierman et al. (1992) \\
\hline pHZ1553 & $\begin{array}{l}\mathrm{pHZ1358} \text { derivative of cosmid } 11 \mathrm{~A} 8 \text { used for replacement of } \\
\text { region } \mathrm{N} 1 \text { in cluster } \mathrm{A} \text {; } t \text { sr aac3(IV) Ltz sti } i^{+} \text {oriT }\end{array}$ & This work (see Fig. 7a) \\
\hline pHZ1581 & $\begin{array}{l}\mathrm{pHZ} 1358 \text { derivative of the cosmid } 18 \mathrm{~A} 2 \text { used for replacement of } \\
\text { region } \mathrm{N} 2 \text { in cluster } \mathrm{A} \text {; } t s \mathrm{aac} 3(\mathrm{IV}) \mathrm{Ltz} s \mathrm{i}^{+} \text {ori } \mathrm{T}\end{array}$ & This work (see Fig. 3) \\
\hline pHZ1586 & $\begin{array}{l}\mathrm{pHZ} 1358 \text { derivative of the cosmid } 2 \mathrm{G} 2 \text { and } 2 \mathrm{~F} 7 \text { used for } \\
\text { replacement of region } \mathrm{N} 3 \text { in cluster } \mathrm{A} ; t s \mathrm{aac} 3(\mathrm{IV}) \text { Ltz sti }{ }^{+} \text {oriT }\end{array}$ & This work (see Fig. 3) \\
\hline
\end{tabular}

* Ltz (lethal zygosis), pock formation caused by plasmid transfer; mel, tyrosinase gene for melanin production; oriT, origin of transfer of plasmid RK2; tsr, thiostrepton resistance gene; aac3(IV), apramycin resistance gene; sti, origin for second-strand synthesis of the multicopy plasmid pIJ101 (Deng et al., 1988).

labelled $18 \mathrm{~kb}, 3.7 \mathrm{~kb}$ and $3.6 \mathrm{~kb}$ PvuII fragments internal to the insert in cosmid $20 \mathrm{H} 7$ from cluster A, $19 \mathrm{~kb}$ and $5.9 \mathrm{~kb} P v u \mathrm{II}$ fragments in cosmid 8D2 from cluster $\mathrm{B}, 7.7 \mathrm{~kb}$ and $2.3 \mathrm{~kb}$ Pvul fragments in cosmid 12B11 from cluster C, $6.7 \mathrm{~kb}$ PvuII fragment in cosmid 7C5 from cluster F, and $3.9 \mathrm{~kb}$ and $3.8 \mathrm{~kb} P v u \mathrm{II}$ fragments in cosmid 17G12 from cluster G hybridized to different AseI fragments (Fig. 5). This supported the hypothesis of distinct PKS gene clusters because none of the inserts in cosmid contigs contain AseI sites. Thus, clusters A, B, $\mathrm{C}, \mathrm{F}$ and G seemed to be fully contained within AseI fragments of 500, 290, 620, 940 and $800 \mathrm{~kb}$, respectively. However, $3.6 \mathrm{~kb}$ and $2.6 \mathrm{~kb}$ PvuII fragments in cosmid 14G12 in cluster D, $3.8 \mathrm{~kb} P v u \mathrm{II}$ fragment in cosmid 6D8 from cluster $\mathrm{E}$ and $7 \mathrm{~kb} P v u \mathrm{II}$ fragment in cosmid 2E4 from cluster $\mathrm{H}$ all hybridized to the $620 \mathrm{~kb}$ Ase I 


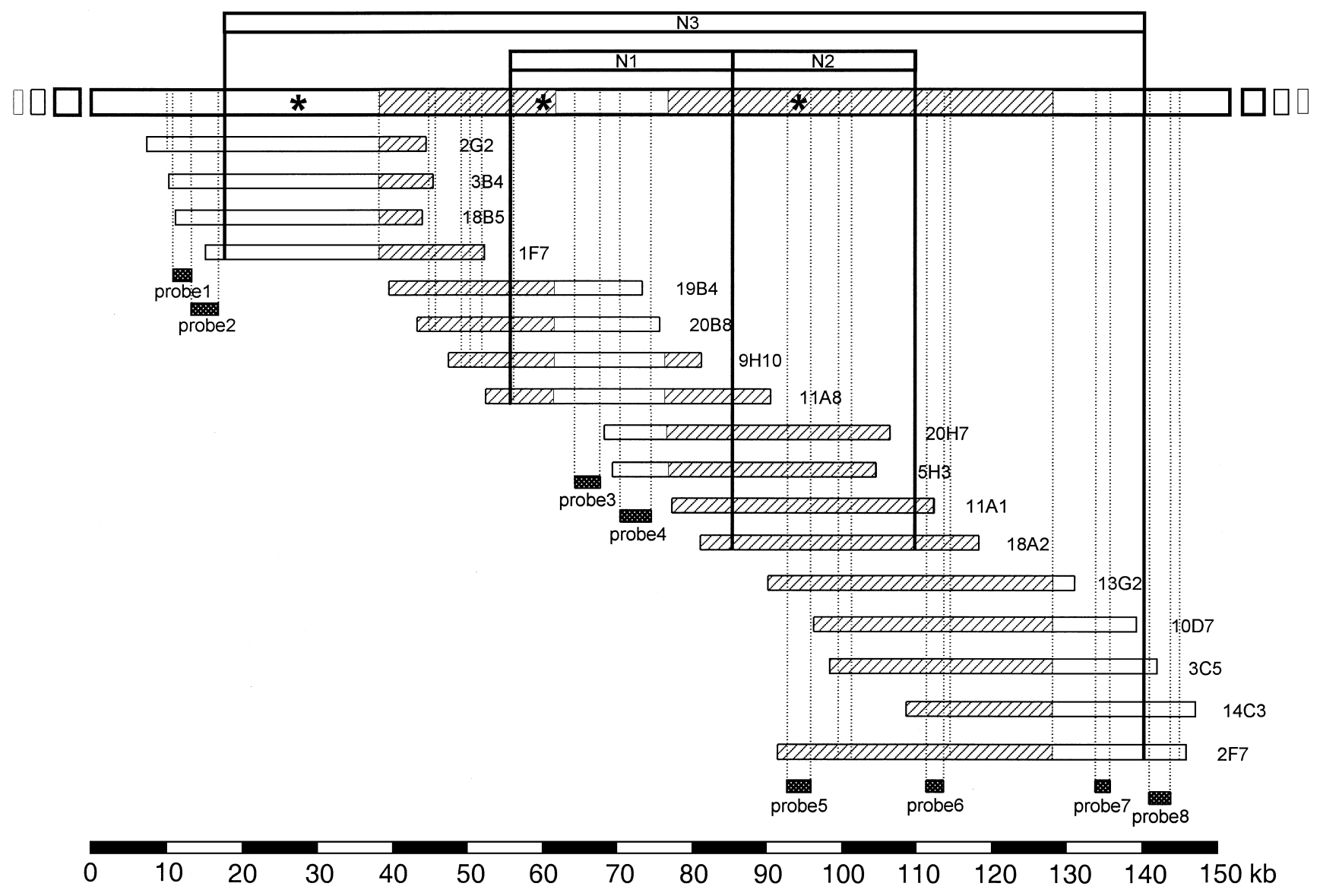

Fig. 3. Overlapping cosmids covering genes for nanchangmycin biosynthesis. Part of the 'Str. nanchangensis' genome containing genes for the biosynthesis of nanchangmycin. Vertical continuous and dotted lines indicate the positions of $\mathrm{BamHI}$ and Pvull sites, respectively. The 17 boxes below indicate individual cosmid clones. Hatching indicates regions hybridizing with the Sac. erythraea erythromycin PKS gene probes. Probes 1-8 (black stippled boxes) were used to confirm ordering of the positive cosmid clones. Replacement of sequences labelled N1-N3 abolished nanchangmycin production. The asterisks represent multiple Pvull fragments whose exact orders have not been determined. A scale is presented below the clones.

fragments, together with cluster C, which were not differentiated further by digestions with DraI and $S s p \mathrm{I}$ because both enzymes resulted in smearing and poor resolution of the chromosomal fragments on PFGE.

\section{A gene cloning system for 'Str. nanchangensis' NS3226}

The regeneration frequency of NS3226 protoplasts was only $0.02 \%$ (measured by comparing microscopic protoplast counts with the numbers of colonies on regeneration medium). Typically, about $6 \%$ of the colonies were derived from nonprotoplasted units that survived dilution in water. Several plasmids failed to give Thio $^{\mathrm{R}}$ (thiostrepton resistant) NS3226 protoplast transformants, even with several micrograms of pure plasmid DNA. These included the sti ${ }^{-}$pIJ101 derivatives pIJ702 and pIJ486 isolated from Streptomyces lividans JT46; sti ${ }^{+}$pIJ101 derivatives pHZ1351 and pHZ1358 (Fig. 6) isolated from E. coli DH5 $\alpha$; SCP2*-derived lowcopy number plasmid vector pIJ922 (Lydiate et al.,
1985); SLP1.2-derived vector pIJ61 (Hopwood et al., 1985); pJV1-derived multi-copy number plasmid vector pWOR120 (Bailey et al., 1986), the last three isolated from Str. lividans JT46. Transformation attempts using the denatured DNA of pIJ702 and pHZ1351 (Fig. 6a) (Oh \& Chater, 1997) also failed. Streptomyces phage $\phi \mathrm{C} 31$ and its derived $a t t^{+}$vector KC301, and $a t t^{-}$vectors KC505, KC515, KC516, KC518, however, could infect 'Str. nanchangensis' NS3226 and form lysogens. Another Streptomyces phage, $\phi \mathrm{HAU} 3$, and its derivatives, pIJ8300 and pIJ8301 (Zhou et al., 1994) could also infect, but not lysogenize, NS3226.

The infection and lysogenization by $\phi \mathrm{C} 31$ and its derivatives of NS3226 prompted us to test the possibility of integrating $\phi \mathrm{C} 31$ attP-containing plasmid in NS3226. A pUC18-derived E. coli plasmid, pSET152 (Bierman et al., 1992), was chosen for this experiment as it carries the $\phi \mathrm{C} 31$ attP site as well as oriT from the E. coli conjugative plasmid RP4. Transfer of this plasmid by conjugation from E. coli to NS3226 could be tested to avoid difficult 
cluster B

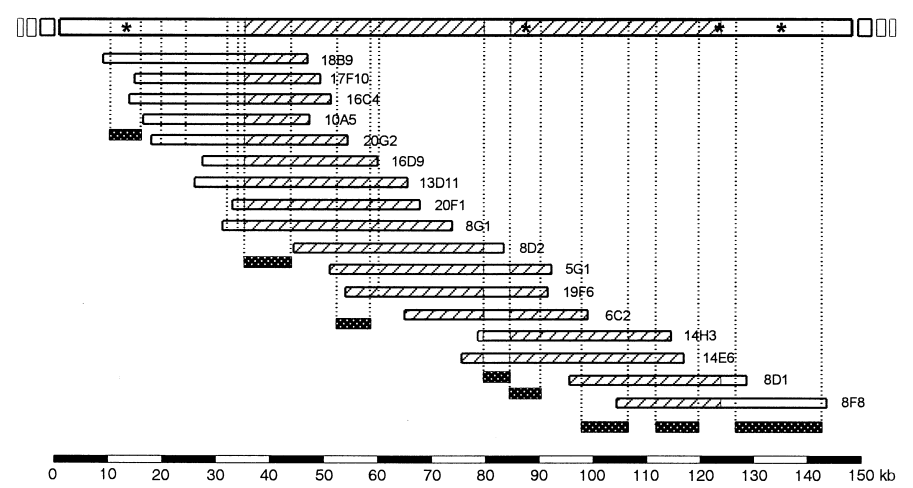

cluster $\mathrm{C}$
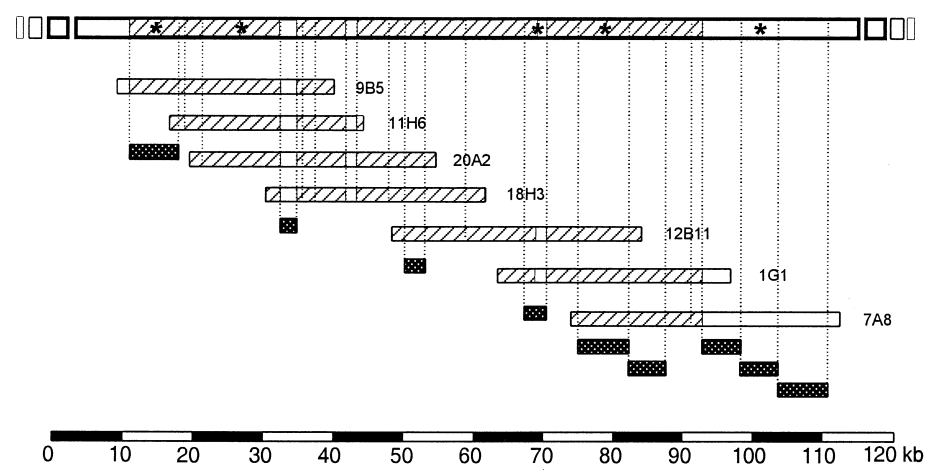

cluster D

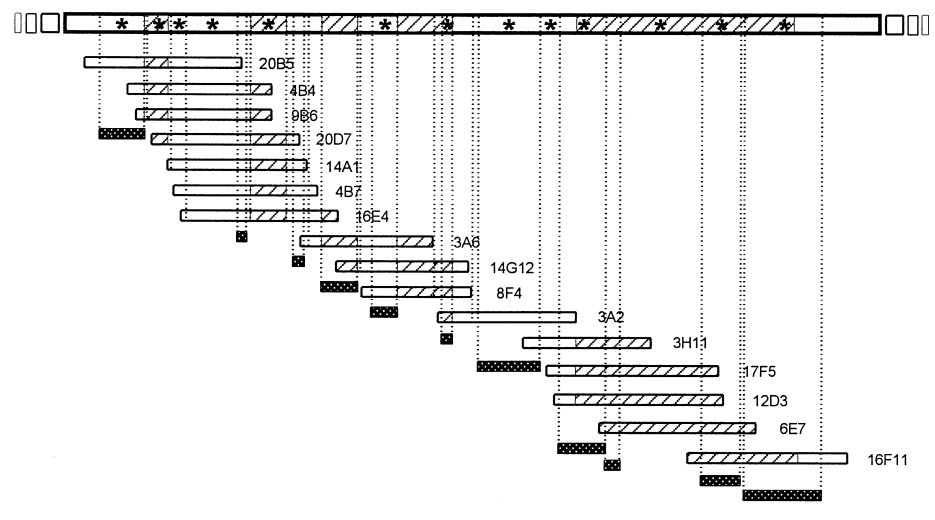

\begin{tabular}{lllllllllllllllllll}
\hline 0 & 10 & 20 & 30 & 40 & 50 & 60 & 70 & 80 & 90 & 100 & 110 & 120 & 130 & 140 & 150 & 160 & 170 & $180 \mathrm{~kb}$
\end{tabular} cluster $\mathrm{E}$

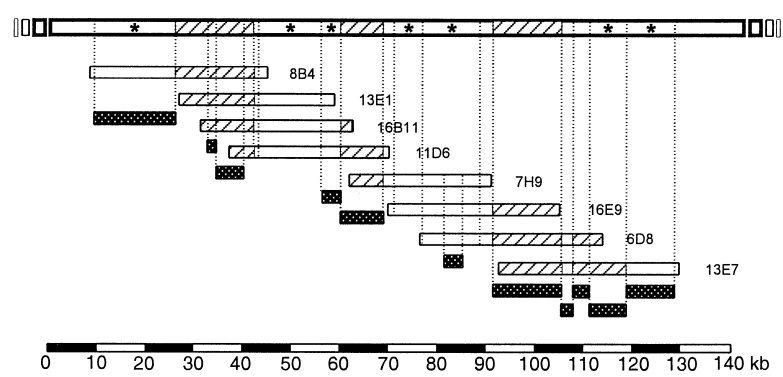

cluster $\mathrm{F}$

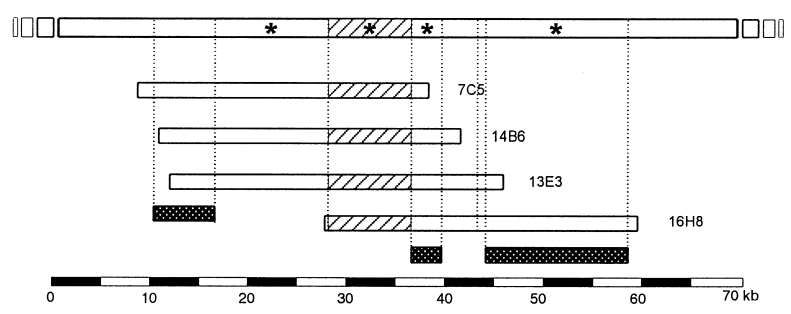

cluster G

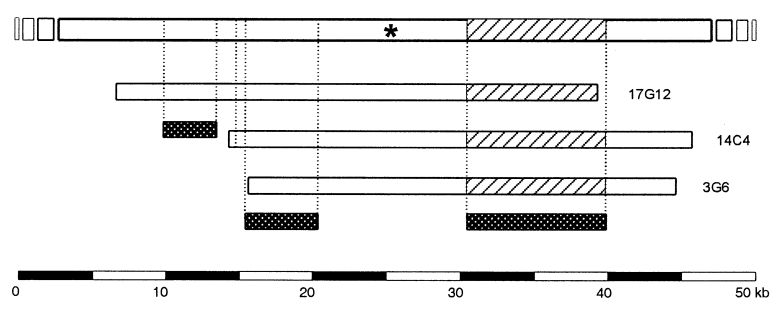

cluster $\mathrm{H}$

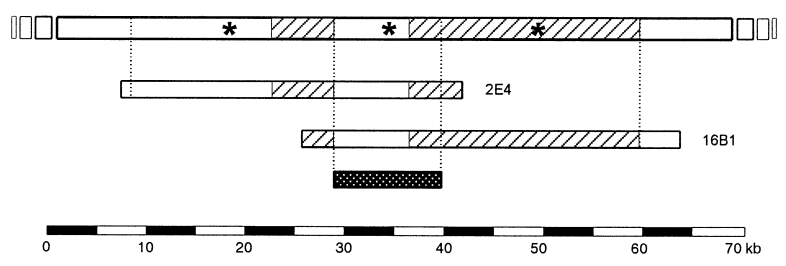

Fig. 4. Clusters $\mathrm{B}-\mathrm{H}$, as ordered by overlapping cosmids and Southern hybridizations. Chromosomal sections representing clusters B-H are shown at the top of each part. Vertical dotted lines indicate the positions of Pvull sites. The horizontal boxes below indicate individual cosmid clones. Hatching indicates regions hybridizing with the Sac. erythraea erythromycin PKS gene probes. Black stippled boxes indicate probes used for Southern hybridization at high stringency $\left(0.2 \times \mathrm{SSC}, 65^{\circ} \mathrm{C}\right)$ for the confirmation of the ordered overlapping cosmids. The asterisks represent multiple Pvull fragments whose exact orders have not been determined. Scales are presented at the bottom of each cluster.

protoplast transformation of the strain. pSET152 was transferred into NS3226 at a high frequency $\left(\sim 10^{-5}\right.$ of the initial viable recipient population), and pSET152 was found to be integrated into the chromosome of strain NS3226 via attP in all of the exconjugants tested. pHZ1358 (Fig. 6b) can also be transferred by con- jugation from E. coli ET12567 carrying an integrated copy of RP4 into NS3226, but it seemed to be very unstable $(\sim 90 \%$ loss after one round of non-selective growth). This feature allowed pHZ1358 (Fig. 6b) to be used efficiently for generating NS3226 mutants by gene replacement (see below). 

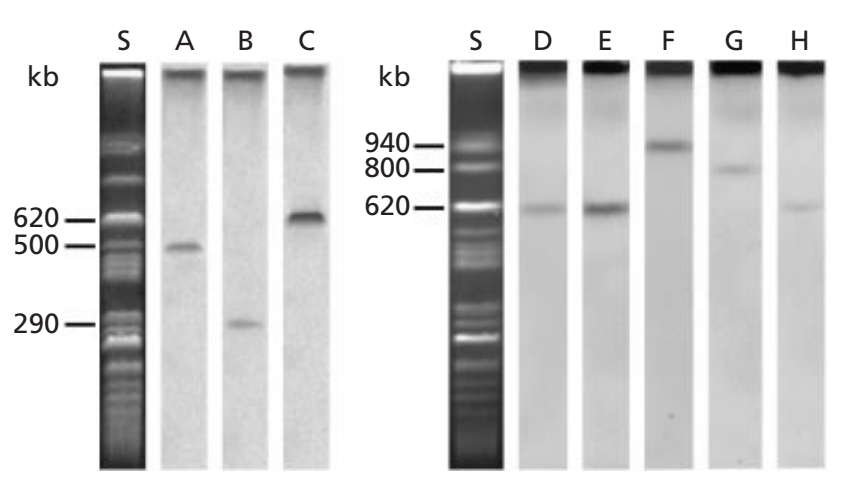

Fig. 5. Mapping of PKS gene clusters $A-H$ on five separate PFGE fragments. Total DNA of 'Str. nanchangensis' NS3226 (example in panels S) was digested with Asel, separated by PFGE ( $1 \%$ agarose gel, $6 \mathrm{~V} \mathrm{~cm}^{-1}$ for $23 \mathrm{~h}$ with a ramped pulse time of 20-80 s) and probed with internal fragments to cosmids $20 \mathrm{H} 7$ (Fig. 3), 8D2, 12B11, 14G12, 6D8, 7C5, 17G12 and 2E4 (cosmids in Fig. 4), which represent cluster $A$ (encoding nanchangmycin production), $B, C, D, E, F, G$ and $H$, respectively. All hybridizations were done at high stringency $\left(0.2 \times \mathrm{SSC}, 65^{\circ} \mathrm{C}\right)$. Sizes are only shown for the corresponding hybridizing Asel fragments. Two batches of gel for blotting are shown.

\section{Cluster A contains genes for nanchangmycin biosynthesis}

Cosmid 11A8, with a $37 \mathrm{~kb}$ insert in the middle of cluster A (Fig. 3), contains the $t s r$ gene suitable for selection in Streptomyces. Its ColE1 origin of replication is nonfunctional in strain NS3226. The pIJ101 origin of replication and sti (second-strand origin of replication) (Deng et al., 1988) are functional but result in extremely unstable replication in strain NS3226. For targeted gene replacement, $26 \mathrm{~kb}$ of the strain NS3226 DNA insert in cosmid $11 \mathrm{~A} 8$ was replaced by a $1.4 \mathrm{~kb}$ apramycin resistance $\left(\mathrm{Apr}^{\mathrm{R}}\right)$ determinant $[\operatorname{aac} 3(I V)]$. This was achieved first by complete digestion of 11A8 DNA by BamHI and religation to obtain pHZ1552 in E. coli. The internal $26 \mathrm{~kb}$ (marked ' $\mathrm{N} 1$ ' in Fig. 3) of the $37 \mathrm{~kb}$ insert in $11 \mathrm{~A} 8$ was found to be deleted and was further replaced by a $1.4 \mathrm{~kb}$ Bam $\mathrm{HI}$ fragment carrying aac $3(\mathrm{IV})$ inserted between $4.8 \mathrm{~kb}$ (proximal to bla) and $5.8 \mathrm{~kb}$ (proximal to oriT) fragments flanking both sides of the deleted region, giving pHZ1553 (Fig. 7a).

pHZ1553 was transferred by conjugation from E. coli ET12567 carrying RP4 into strain NS3226. About $10^{-7}$ exconjugants per donor were obtained which were initially selected to be $\mathrm{Thio}^{\mathrm{R}}$. These colonies were also $\mathrm{Apr}^{\mathrm{R}}$ and thus presumably contained $\mathrm{pHZ1553}$ either replicating autonomously or integrated into the host genome by homologous recombination. Such colonies were inoculated onto GS medium containing apramycin and screened by replica plating for thiostrepton sensitivity. About $90 \%$ of the colonies were Thios and thus had probably lost the pIJ101-derived vector part of pHZ1553 (Fig. 7a, step 2). This was confirmed for two $\mathrm{Apr}^{\mathrm{R}}$ Thio $^{\mathrm{S}}$ isolates by probing a Southern transfer of total DNA (Fig. 7b) with a labelled $17 \cdot 4 \mathrm{~kb}$ PvuII
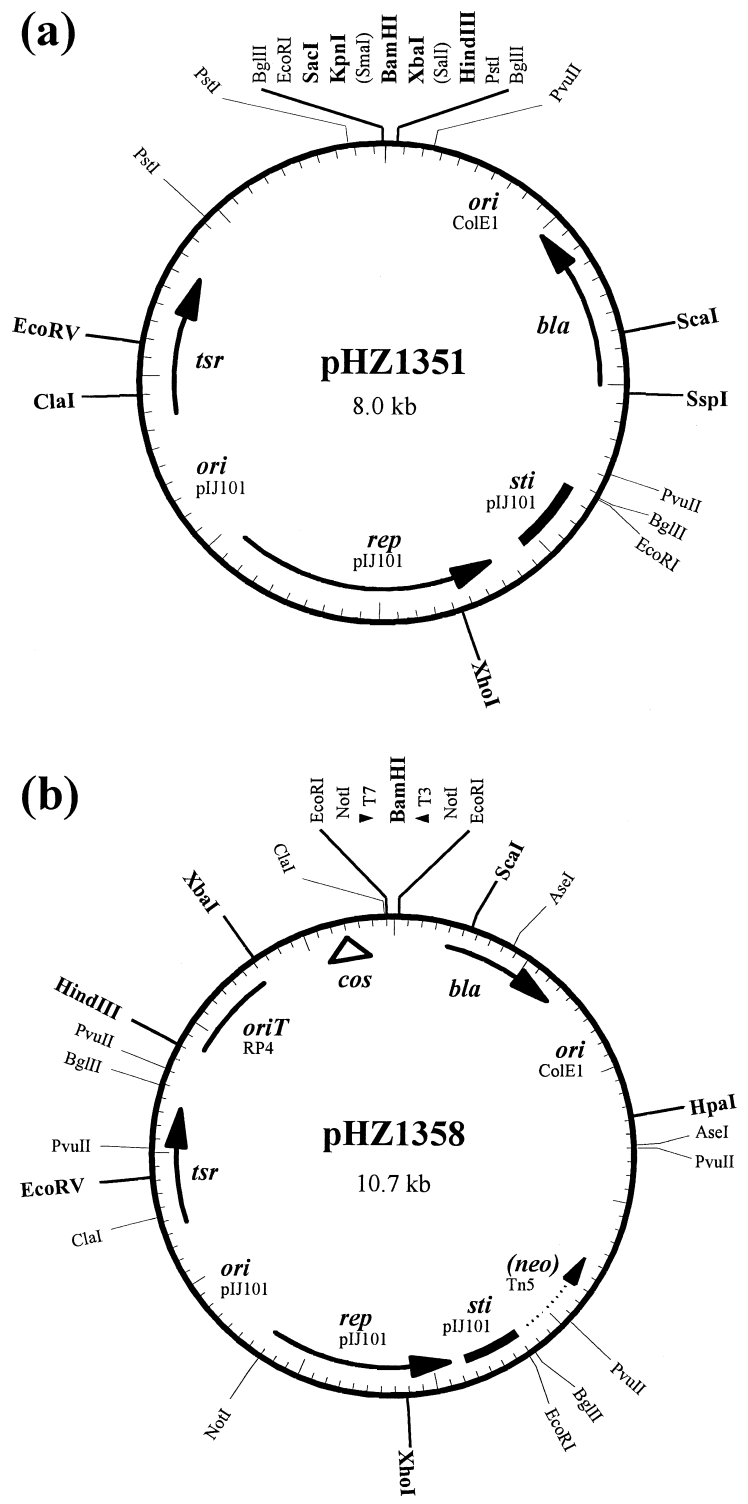

Fig. 6. Bifunctional plasmid vectors $\mathrm{pHZ1351}$ (a) and $\mathrm{pHZ1358} \mathrm{(b).} \mathrm{bla,} \beta$-lactamase gene; tsr, thiostrepton resistance $\left(\right.$ Thio $\left.^{\mathrm{R}}\right)$ gene; $s \mathrm{i}^{+}$, strong incompatibility region, containing a single-strand origin of replication (Deng et al., 1988); cos, phage $\lambda$ cos site; oriT, origin of transfer of plasmid RP4; T3 and T7, promoters specifically recognized by the phage T3 and T7 RNA polymerases; (neo), promoterless kanamycin resistance gene from Tn5. rep is the plJ101 replication gene [a spontaneous mutation removing the unique $\mathrm{BamHI}$ site in the rep region of pIJ101 as detected by Kieser et al. (1982) is a change from ccgGatcctc to ccgAatcctc with no detectable phenotypic changes]. The unique sites are shown in bold.

fragment from pHZ1553 (Fig. 7a). Two of the presumed double crossover recombinants were tested for their ability to inhibit Bacillus cereus 1126. The NS3226 control gave inhibition zones of about $16 \mathrm{~mm}$ diameter while the two candidate strains grew normally but produced no inhibition zone. The non-production of nanchangmycin was further confirmed by HPLC analy- 
(a)
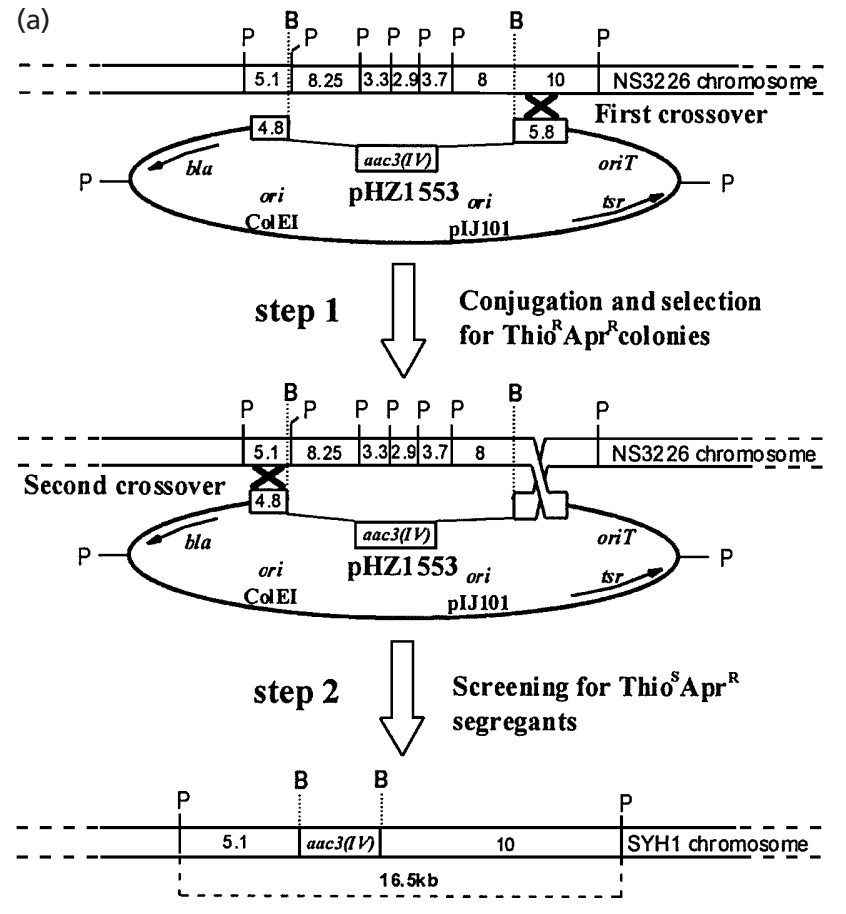

(b)

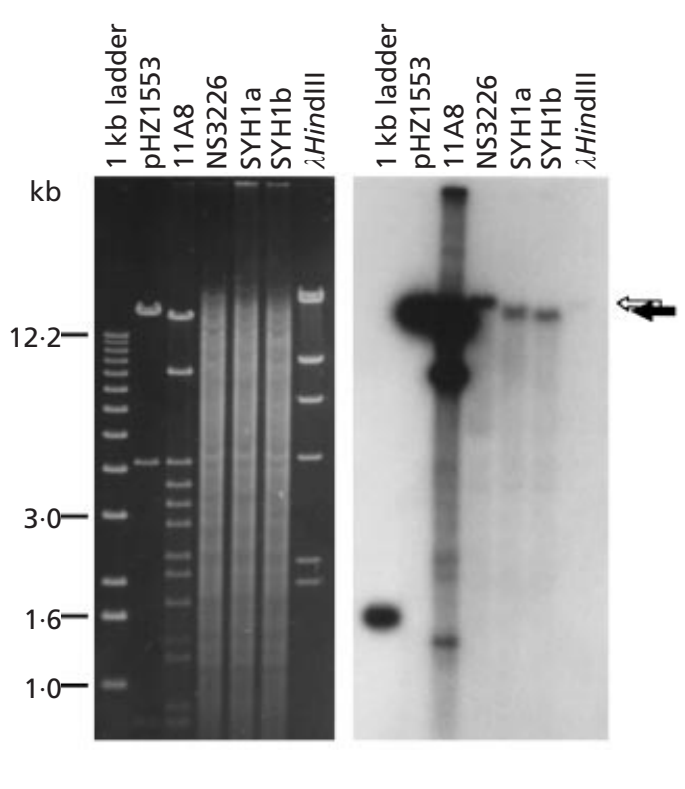

Fig. 7. Schematic representation (a) of the replacement of part of the PKS gene cluster A in strain NS3226 using pHZ1553, constructed by substitution of the internal BamHI fragment of cosmid 11A8 (Fig. 3) by aac3(IV). Refer to (b) for details of other parts of the vector. A total of $\sim 26 \mathrm{~kb}$ contiguous fragments between the two BamHI sites in NS3226 should be deleted and replaced by the $1.4 \mathrm{~kb}$ aac3(IV) fragment. The genome of SYH1 should have a $16.5 \mathrm{~kb}$ new Pvull fragment. B, BamHI; P, Pvull. (b) Ethidium bromide-stained agarose gel and Southern transfer probed with the labelled $17.4 \mathrm{~kb}$ Pvull fragment of pHZ1553 containing aac3(IV), and 4.8 and $5.8 \mathrm{~kb}$ flanking PKS-homologous regions. All the DNA samples were digested with Pvull. SYH1a and SHY1b are two independent $\mathrm{Apr}^{\mathrm{R}} \mathrm{Thio}^{\mathrm{S}}$ derivatives of NS3226. The black arrow points to the $16.5 \mathrm{~kb}$ new fragment formed as a sum of $1.4 \mathrm{~kb}$ aac3(IV) plus $5.1 \mathrm{~kb}$ and part of the $18 \mathrm{~kb}$ PKShomologous regions in NS3226 after gene replacement, which is clearly smaller than the original fragment in NS3226 as indicated by a white arrow. The positions of the size markers ( $1 \mathrm{~kb}$ ladder and $\lambda$ DNA digested with HindIII) are indicated to the left and right of the gel, respectively. A $1.6 \mathrm{~kb}$ hybridizing signal detected in the $1 \mathrm{~kb}$ ladder (size markers) is the result of hybridization between this fragment (originating from pBR322) and part of the probe fragment carrying bla.
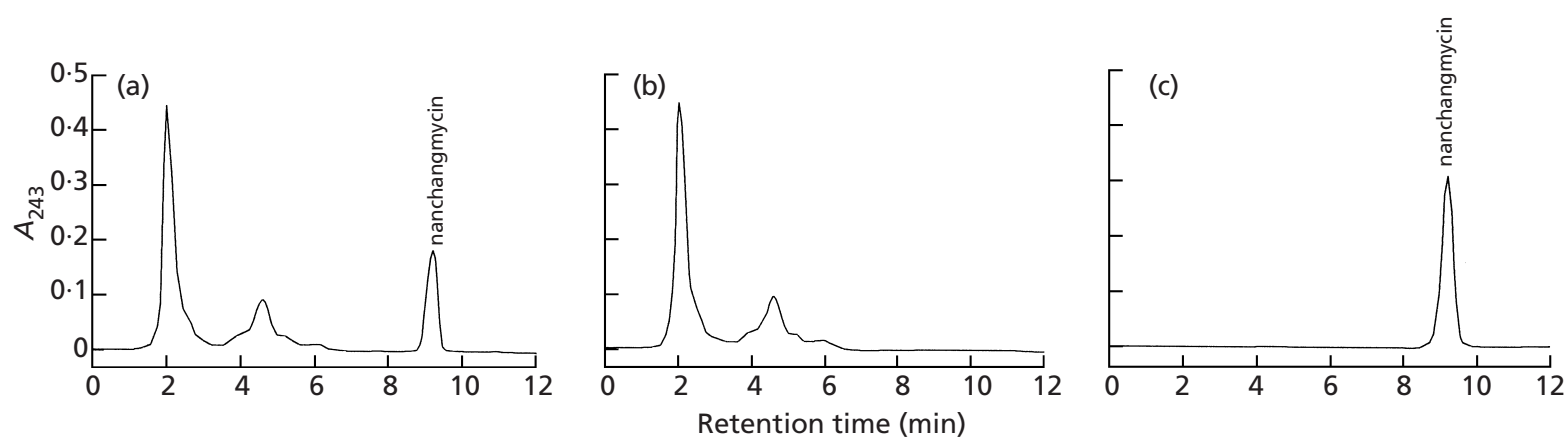

Fig. 8. HPLC analysis of nanchangmycin production by the strains after gene replacement. Nanchangmycin was extracted from the mycelium of NS3226 (a) and SYH1a (b) by methanol extraction. Pure nanchangmycin (c) was used as standard. Peaks corresponding to nanchangmycin can be seen in (a) and (c) but not in (b).

sis of the fermentation products. No peak appeared from the samples purified from independent candidate strains corresponding to the peaks of a standard sample of nanchangmycin and a sample isolated from wild-type NS3226 (Fig. 8). This was consistent with the hypothesis that genes involved in nanchangmycin biosynthesis were disrupted. An experiment using the same strategy for the replacement of the $25 \mathrm{~kb} \mathrm{BamHI}$ fragment internal to cosmid 18A2 (marked 'N2' in Fig. 3) by ac3(IV) also abolished nanchangmycin production. 
Another gene replacement experiment resulted in removal of $\sim 120 \mathrm{~kb}$ DNA sequence, perhaps containing an almost complete gene cluster for nanchangmycin biosynthesis, from the chromosome of NS3226. Again, the vector ( $\mathrm{pHZ1586)}$ was derived from pHZ1358 (Fig. $6 \mathrm{~b})$. The $8.4 \mathrm{~kb}$ DNA sequence flanking the leftmost BamHI sites (shown in Fig. 3) of the cosmid 2G2 is designated 'left arm' and $4.3 \mathrm{~kb}$ DNA sequence flanking the rightmost Bam HI sites (Fig. 3) of the cosmid 2F7 is designated 'right arm' for the desired double crossovers, and aac3(IV) is inserted between the two BamHI sites. The NS3226 derivative SYH8 obtained after double crossing over was confirmed by Southern hybridization (not shown) to have the N3 region (Fig. 3) removed from the chromosome and no nanchangmycin production could be detected either by bioassay using B. cereus 1126 as the indicator strain or by HPLC analysis.

\section{DISCUSSION}

It is striking that a $3.2 \mathrm{~kb}$ heterologous type I PKS gene fragment from DEBS3 of the erythromycin producer Sac. erythraea strongly hybridized to 90 of the 1920 cosmids in the NS3226 cosmid library, corresponding to $\sim 5 \%$ of the genomic sequence. Ordering of the hybridizing clones produced eight separate contigs each consisting of 2-17 cosmids clones and covering 37$174 \mathrm{~kb}$. Respective single cosmid probes, from each of the eight PKS clusters hybridized to five different 'Str. nanchangensis' AseI fragments fractionated by PFGE, suggesting that multiple PKS gene clusters had been isolated. However, the presence of eight separate contigs here should not be simply taken as conclusive evidence that 'Str. nanchangensis' has eight independent PKS gene clusters encoding eight non-aromatic polyketide biosynthetic pathways, because none of them had been confirmed by DNA sequencing and only one of the gene clusters was verified to encode nanchangmycin production. The other known secondary metabolite produced by 'Str. nanchangensis', meilingmycin, is assumed to be encoded by another cluster, but we know nothing about the other six clusters whose encoded products could be relevant to polyketide synthesis.

Our data presented here imply that micro-organisms may encode many more secondary metabolites than are readily detectable in standard fermentation. While the overwhelming study of polyketide biosynthetic gene clusters in micro-organisms, especially Streptomyces, is experiencing many exciting breakthroughs, the genetic, and thus their encoded metabolite, diversities might still be far from thorough understanding. The identification of six to eight PKS gene clusters in a single Sorangium cellulosum strain, which is known to produce only epothilone, had also been reported by Santi et al. (2000). We suspect that type I PKS-like pathways could be a common theme among many different bacteria, apart from most commonly studied actinomycetes. Using conserved or even heterologous PKS probes for identifying unknown PKS gene clusters (or potential secondary metabolite pathways), especially in micro- organisms other than, for example, Streptomyces or Myxobacterium, for discovering the new polyketide compounds may have significant implications.

The identification and isolation of multiple PKS genes in a single strain could provide an opportunity for isolating 'Str. nanchangensis' derivatives that produce only one of the antibiotics but in increased quantities, as the biosynthesis of compounds derived from similar precursors in the same cell might be competitive. Thus an increase in production, or selective antibiotic production, could be achieved by selective cluster-specific mutagenesis by gene replacement, as we have demonstrated. Indeed, the deletion of a large DNA fragment by gene replacement (not shown) in cluster C (Fig. 4) resulted in at least a threefold increase of the nanchangmycin production as detected by bioassay, but no obvious increase for meilingmycin production was detected in the disrupted strains for clusters A-C (data not shown). An example of successful selective production of avermectin compounds, obviating the need for separation of avermectin and oligomycin by knocking out oligomycin production in an avermectin producer by Tn4560 mutagenesis had been reported by Ikeda \& Omura (1995). The unknown or unwanted clusters could be deleted in a stepwise manner. Such targeted deletions should have no danger of introducing deleterious mutations elsewhere in the chromosome, which would otherwise affect, for example, cell growth.

A search of the isolated multiple PKS clusters for the ones that could be involved in nanchangmycin or meilingmycin biosynthesis led to the discovery of the cluster that is essential for the former. Several DNA fragments in clusters A-C respectively were disrupted or replaced for targeted mutations to achieve this result, although none of the three clusters were found to encode meilingmycin production. To our knowledge, the identification of a large region involved in nanchangmycin production would constitute a first documented example of what seems to be a complete polyether antibiotic biosynthesis gene cluster. The coverage of $89 \mathrm{~kb}$ PKShomologous DNA (Fig. 3) involved in the biosynthesis of nanchangmycin (Fig. 1) strongly supports the hypothesis of a modular organization for polyether biosynthesis, as has been reported for macrolide and other antibiotics. We tend to think that the interruption of the $89 \mathrm{~kb}$ PKS-homologous region by a $12 \mathrm{~kb}$ PKS-nonhomologous region is not a division of two independent PKS clusters, but all necessary for nanchangmycin production. Based on erythromycin and avermectin examples, a 'standard' PKS module appears to be encoded by $\sim 5 \mathrm{~kb}$ of DNA (Bevitt et al., 1992; Donadio \& Katz, 1992; MacNeil et al., 1992). The DNA encoding the PKS for the nanchangmycin polyether production would require at least $70 \mathrm{~kb}$ of genetic information; enough for 14 modules. The $89 \mathrm{~kb}$ PKS-homologous region might be a maximal estimate because four PvuII end fragments flanking the two separate contigs (Fig. 3) may only have a partial PKS-homologous region. The most interesting and possibly unique enzymes for polyether biosynthesis would be the cyclase(s) that 
catalyses the cascade of cyclizations to form the polyether structure, but such new information will have to wait until the gene cluster is sequenced: this work is now in progress. The genetic information required for such enzymes [or/and additional genes necessary for the sidegroup (Fig. 1) biosynthesis] could either be located in the $12 \mathrm{~kb}$ DNA sandwiched between two PKS-homologous regions or flanking both sides of the PKS-homologous regions. The interrupted PKS regions in a single PKS pathway had also been reported in other clusters, including avermectin (MacNeil et al., 1992; Ikeda et al., 1999).

'Str. nanchangensis' NS3226 is refractory to transformation by plasmid DNA from E. coli or Str. lividans, possibly because of the poor frequency of protoplast regeneration, and/or strong restriction system(s). Such problems were circumvented effectively by the development of mobilized conjugation of Streptomyces-E. coli shuttle cosmid vectors, also carrying oriT from RP4, from E. coli to 'Str. nanchangensis'. Most significant is the construction and efficient utilization of replicative Streptomyces plasmids derived from pIJ101 for generating mutations by targeted gene disruption and replacement experiments, which were used in this study for the demonstration that a specific gene cluster was involved in antibiotic production. Different from the suicide plasmids or temperature-sensitive Streptomyces plasmid vectors frequently used so far for gene disruption and replacement, pHZ1351 and pHZ1358 (Fig. 6) are replicative but genetically very unstable in 'Str. nanchangensis'. Fewer than 1 in 1000000 colonies lost thiostrepton resistance and thus still could carry plasmids after one round of non-selective growth. pHZ1351 (Fig. 6a) has a polylinker cloning site and can be propagated both in Streptomyces and in E. coli. pHZ1358 (Fig. 6b) has additionally the origin of transfer of the conjugative plasmid RP4 for efficient conjugative transfer from E. coli to Streptomyces, and a phage $\lambda$ cos site flanked by T3 and T7 promoters for the efficient generation of ordered cosmid libraries. It is not clear whether sti has anything to do with the structural stability of the plasmids as has been suggested by Zaman et al. (1993) and Pigac et al. (1988) because there are also structurally stable plasmids such as pIJ702 that lack this function, and a case of instability of pIJ702 and its use for gene disruption experiments had been reported in Sac. erythraea (Weber et al., 1990). The extreme segregational instability of pHZ1351 (Fig. 6a) and pHZ1358 (Fig. 6b) is likely to be caused by a spontaneous deletion of the $693 \mathrm{bp}$ fragment which we have characterized between rep and $s t i$, a region suggested to be required for plasmid maintenance (Kieser et al., 1982).

Successful gene replacement experiments using pHZ1351 or pHZ1358 were also performed for mutagenizing a peptide pathway gene in Streptomyces hygroscopicus 10-22 and a polyene pathway gene in Streptomyces sp. FR008 in our laboratory (unpublished results) and in other laboratories, for mutagenizing the milbemycin PKS of Streptomyces griseochromogenes (P.
Dyson, personal communication) and the clavulanic acid pathway of Streptomyces clavuligerus, a goal that could not be achieved with many other vector plasmids (P. Liras, personal communication).

\section{ACKNOWLEDGEMENTS}

Work in China was supported by the Natural Science Foundation of China (NSFC), Ministry of Education, the Ministry of Science and Technology, Shanghai Municipal Council of Science and Technology, and the International Foundation for Science. Work at the John Innes Centre was supported by the John Innes Foundation. X. Zhou gratefully acknowledges support from a joint project between the Huazhong Agricultural University and the John Innes Centre, funded in part by the Royal Society and the British Council; $Z$. Deng acknowledges a Career Fellowship from the Rockefeller Foundation. We thank K. F. Chater and P. F. Leadlay for the gifts of plasmids, phage vectors, probes and strains. We thank Dr Ben Shen for helpful discussions and suggestions. We are very grateful to Sir David Hopwood and Keith Chater for their continuous support and encouragement throughout this study, and critical reading of the manuscript.

\section{REFERENCES}

Bailey, C. R., Bruton, C. J., Butler, M. J., Chater, K. F., Harris, J. E. \& Hopwood, D. A. (1986). Properties of in vitro recombinant derivatives of pJV1, a multi-copy plasmid from Streptomyces phaeochromogenes. J Gen Microbiol 132, 2071-2078.

Bevitt, D. J., Cortes, J., Haydock, S. F. \& Leadlay, P. F. (1992). 6Deoxyerythronolide-B synthase 2 from Saccharopolyspora erythraea: cloning of the structural gene, sequence analysis and inferred domain structure of the multifunctional enzyme. Eur $J$ Biochem 204, 39-49.

Bierman, M., Logan, R., O’Brien, K., Seno, E. T., Rao, R. N. \& Schoner, B. E. (1992). Plasmid cloning vectors for the conjugal transfer of DNA from Escherichia coli to Streptomyces spp. Gene 116, 43-49.

Borck, K., Beggs, J. D., Brammer, W. J., Hopkens, A. S. \& Murray, N. E. (1976). The construction in vitro of transducing derivatives of phage lambda. Mol Gen Genet 146, 199-207.

Burg, R. W., Miller, B. M., Baker, E. E. \& 12 other authors (1979). Avermectin, new family of potent anthelmintic agents: producing organism and fermentation. Antimicrob Agents Chemother 15, 361-367.

Cane, D. E., Walsh, C. T. \& Khosla, C. (1998). Harnessing the biosynthetic code: combinations, permutations, and mutations. Science 282, 63-68.

Cortes, J., Haydock, S. F., Roberts, G. A., Bevitt, D. J. \& Leadlay, P. F. (1990). An unusually large multifunctional polypeptide in the erythromycin-producing polyketide synthase of Saccharopolyspora erythraea. Nature 348, 176-178.

Czerwinski, E. W. \& Steinrauf, L. K. (1971). Structure of the antibiotic dianemycin. Biochem Biophys Res Commun 45, 1284-1287.

Deng, Z. X., Kieser, T. \& Hopwood, D. A. (1988). 'Strong incompatibility' between derivatives of the Streptomyces multicopy plasmid pIJ101. Mol Gen Genet 214, 286-294.

Donadio, S. \& Katz, L. (1992). Organization of the enzymatic domains in the multifunctional polyketide synthase involved in erythromycin formation in Saccharopolyspora erythraea. Gene 111, 51-60. 
Donadio, S., Staver, M. J., McAlpine, J. B., Swanson, S. J. \& Katz, L. (1991). Modular organization of genes required for complex polyketide biosynthesis. Science 252, 675-679.

Evans, G. A., Lewis, K. \& Rothenberg, B. E. (1989). High efficiency vectors for cosmid microcloning and genomic analysis. Gene 79, 9-20.

Hanahan, D. (1983). Studies on transformation of Escherichia coli with plasmids. J Mol Biol 166, 557-580.

Hopwood, D. A. (1997). Genetic contributions to understanding polyketide synthases. Chem Rev 97, 2465-2497.

Hopwood, D. A., Bibb, M. J., Chater, K. F. \& 7 other authors/ editors (1985). Genetic Manipulation of Streptomyces: a Laboratory Manual. Norwich: John Innes Foundation.

Hu, Z., Bao, K., Zhou, X., Zhou, Q., Hopwood, D. A., Kieser, T. \& Deng, Z. (1994). Repeated polyketide synthase modules involved in the biosynthesis of a heptaene macrolide by Streptomyces sp. FR-008. Mol Microbiol 14, 163-172.

Hutchinson, C. R. (1998). Combinatorial biosynthesis for new drug discovery. Curr Opin Microbiol 1, 319-329.

Ikeda, H. \& Omura, S. (1995). Control of avermectin biosynthesis in Streptomyces avermitilis for the selective production of a useful component. J Antibiot 48, 549-562.

Ikeda, H., Nonomiya, T., Usami, M., Ohta, T. \& Omura, S. (1999). Organization of the biosynthetic gene cluster for the polyketide anthelmintic macrolide avermectin in Streptomyces avermitilis. Proc Natl Acad Sci US A 96, 9509-9514.

Janssen, G. R. \& Bibb, M. J. (1993). Derivatives of pUC18 that have $B g l I I$ sites flanking a modified multiple cloning site and that retain the ability to identify recombinant clones by visual screening of Escherichia coli colonies. Gene 124, 133-134.

Katz, L. (1997). Manipulation of modular polyketide synthases. Chem Rev 97, 2557-2576.

Katz, L. \& McDaniel, R. (1999). Novel macrolides through genetic engineering. Med Res Rev 19, 543-558.

Katz, E., Thompson, C. J. \& Hopwood, D. A. (1983). Cloning and expression of the tyrosinase gene from Streptomyces antibioticus in Streptomyces lividans 66. J Gen Microbiol 129, 2703-2714.

Kieser, T., Hopwood, D. A., Wright, H. M. \& Thompson, C. J. (1982). pIJ101, a multi-copy broad host-range Streptomyces plasmid: functional analysis and development of DNA cloning vectors. Mol Gen Genet 185, 223-238.

Kieser, T., Bibb, M. J., Buttner, M. J., Chater, K. F. \& Hopwood, D. A. (2000). Practical Streptomyces Genetics. Norwich: John Innes Foundation.

Leadlay, P. F. (1997). Combinatorial approaches to polyketide biosynthesis. Curr Opin Chem Biol 1, 162-168.

Lomovskaya, N. D., Mkrtumian, N. M., Gostimskaya, N. L. \& Danilenko, V. N. (1972). Characterization of temperate actinophage $\phi \mathrm{C} 31$ isolated from Streptomyces coelicolor A3(2). J Virol 9, 258-262.

Lydiate, D. J., Malpartida, F. \& Hopwood, D. A. (1985). The Streptomyces plasmid SCP2*: its functional analysis and development into useful cloning vectors. Gene 35, 223-235.

MacNeil, D. J., Gewain, K. M., Ruby, C. L., Dezeny, G., Gibbons, P. H. \& MacNeil, T. (1992). Analysis of Streptomyces avermitilis genes required for avermectin biosynthesis utilizing a novel integration vector. Gene 111, 61-68.
Oh, S.-H. \& Chater, K. F. (1997). Denaturation of circular or linear DNA facilitates targeted integrative transformation of Streptomyces coelicolor A3(2): possible relevance to other organisms. J Bacteriol 179, 122-127.

Ouyang, L., Wan, S., Tu, G., Chen, X., Zhen, Y. \& Gao, Y. (1984). A new species of Streptomyces producing insecticidal antibiotics. Chin J Microbiol 24, 195-199.

Ouyang, L., Tu, G., Gao, Y., Zhang, P. \& Xie, X. (1993). Two insecticidal antibiotics produced by Streptomyces nanchangensis. J Jiangxi Agricul Univ 15, 148-153.

Pigac, J., Vujaklija, D., Toman, Z., Gamulin, V. \& Schrempf, H. (1988). Structural instability of a bifunctional plasmid pZG1 and single-stranded DNA formation in Streptomyces. Plasmid 19, 222-230.

Sambrook, J., Fritsch, E. F. \& Maniatis, T. (1989). Molecular Cloning: a Laboratory Manual, 2nd edn. Cold Spring Harbor, NY: Cold Spring Harbor Laboratory.

Santi, D. V., Siani, M. A., Julien, B., Kupfer, D. \& Roe, B. (2000). An approach for obtaining perfect hybridization probes for unknown polyketide synthase genes: a search for the epothilone gene cluster. Gene 247, 97-102.

Schwecke, T., Aparicio, J. F., Molnar, I. \& 10 other authors (1995). The biosynthetic gene cluster for the polyketide immunosuppressant rapamycin. Proc Natl Acad Sci US A 92, 7839-7843.

Takahashi, S., Miyaoka, H., Tanaka, K., Enoktta, R. \& Okazaki, T. (1993). Milbemycin a11, a12, a13, a14, and a15, a new family of milbemycins from Streptomyces hygroscopicus ssp. aureolacrimosus, taxonomy, fermentation, isolation, structure elucidation and biological properties. J Antibiot 49, 1364-1371.

Thompson, C. J., Kieser, T., Ward, J. M. \& Hopwood, D. A. (1982). Physical analysis of antibiotic-resistant genes from Streptomyces and their use in vector construction. Gene 20, 51-62.

Tsai, J. F.-Y. \& Chen, C. W. (1987). Isolation and characterization of Streptomyces lividans mutants deficient in intraplasmid recombination. Mol Gen Genet 208, 211-218.

Ward, J. M., Janssen, G. R., Kieser, T. \& Bibb, M. J. (1986). Construction and characterization of a series of multi-copy promoter-probe plasmid vectors for Streptomyces using the aminoglycoside phosphotransferase gene from Tn5 as indicator. Mol Gen Genet 203, 468-478.

Weber, J. M., Leung, J. O., Maine, G. T., Potenz, R. H., Paulus, T. J. \& DeWitt, J. P. (1990). Organization of a cluster of erythromycin genes in Saccharopolyspora erythraea. J Bacteriol 172, 2372-2383.

Xue, Y., Zhao, L., Liu, H.-W. \& Sherman, D. H. (1998). A gene cluster for macrolide antibiotic biosynthesis in Streptomyces venezuelae: architecture of metabolic diversity. Proc Natl Acad Sci U S A 95, 12111-12116.

Zaman, S., Radnedge, L., Richards, H. \& Ward, J. M. (1993). Analysis of the site for second-strand initiation during replication of the Streptomyces plasmid pIJ101. J Gen Microbiol 139, 669-676.

Zhou, X., Deng, Z., Hopwood, D. A. \& Kieser, T. (1994). Characterization of HAU3, a broad-host-range temperate Streptomyces phage, and development of plasmids. J Bacteriol 176, 2096-2099.

Received 15 May 2001; revised 29 August 2001; accepted 9 October 2001. 